Bogdan Walczak

Państwowa Wyższa Szkoła Zawodowa

im. Jakuba z Paradyża w Gorzowie Wielkopolskim

\title{
CHREMATONIMIA - NAJBARDZIEJ DZIŚ DYNAMICZNA KATEGORIA NAZEWNICZA
}

Choć chrematonimy (nazwy własne wytworów człowieka) sięgają swymi początkami odległej przeszłości (na przykład starożytności sięgają nazwy statków czy mieczów, średniowiecza - nazwy pucharów czy dzwonów itd.), dopiero obecnie stanowią one najbardziej produktywną klasę nazw własnych [Kosyl, 2001, s. 448]. Zakres terminu „chrematonim” jest do dzisiaj sporny. Rodzą się tu wątpliwości dwojakiego rodzaju. Pierwsze dotyczą przynależności do chrematonimów niematerialnych wytworów myśli ludzkiej (tzw. ideonimów czy socjonimów) lub usytuowania w obrębie propriów - nazw kin, teatrów, will, domów wczasowych, lokali gastronomicznych i handlowych, zakładów przemysłowych itd. - chrematonimów czy urbanonimów [Kosyl, 2001], drugie - statusu (propria czy appellativa) takich chrematonimów jak nazwy firmowe, czyli firmonimy [zob. na ich temat Lewandowski, 1992]. O ile bowiem dawne chrematonimy (jak nazwy dzwonów - Zygmunt, dział - Bazyliszek czy statków - Panna Wodna) istotnie oznaczały pojedyncze, mające jednostkowe, indywidualne właściwości, wytwory ręki ludzkiej, o tyle współczesne chrematonimy

[...] odnoszą się [...] zwykle do całej serii identycznych z założenia przedmiotów (mnogość jednorodna), a jednocześnie do poszczególnych okazów tej serii. Ze względu na ten szczególny zakres użycia nazwy te zbliżają się do wyrazów pospolitych (istnienie wielu desygnatów sprzyja wytwarzaniu się sfery pojęciowej) i mogą być traktowane jako ka te goria przejściowa między nazwami własnymi a pospolitymi. Znajduje to odbicie w przepisach ortograficznych. Zalecają one stosowanie dużej litery w takich wypadkach, gdy chodzi wyraźnie o nazwę firmową, markę, serię, typ wyrobu przemysłowego, np. fabryka produkuje samochód marki Warszawa; nadszedt transport papierosów Giewont. Małej litery używa się wówczas, gdy chodzi o nazwy poszczególnych, jednostkowych przedmiotów: jechać warszawa, palić giewonta [Kosyl, 2001, s. 448]. 
Sam swego czasu włączyłem się do dyskusji na temat statusu firmonimów [Walczak, 2000]. Nie wchodząc w tym miejscu w szczegóły, ogólnie można stwierdzić, że zasadne wydaje się traktowanie przynajmniej niektórych rodzajów chrematonimów jako swego rodzaju obszaru przejściowego między nazwami własnymi a wyrazami pospolitymi.

Niezależnie od tych teoretycznych sporów i wątpliwości, chrematonimy stanowią dziś, jak już stwierdziliśmy wyżej, najbardziej produktywną klasę nazw własnych. Jak słusznie konstatuje Artur Gałkowski, „[...] chrematonimy, jako stosunkowo nowy, ale dynamicznie poszerzający się zbiór onimiczny, są kategorią nazw własnych, spełniających istotne role językowe, które można rozpatrywać z punktu widzenia użytkowego i kulturowego" [Gałkowski, 2008, s. 11]. Jest to dzisiaj:

[...] najbogatszy dział onimii w ogóle, do tego bardzo żywotny, pozornie nieokiełznany i czerpiący inspiracje formalne zarówno z systemu apelatywów, jak i istniejącego już systemu propriów. Wykorzystywane $\mathrm{w}$ nim techniki nazewnicze budują specjalną retorykę nazw na użytek jednostek i społeczeństw. Nazewnictwo kulturowo-użytkowe to najbardziej czynny zasób onimiczny z komunikacyjnego i tekstowego punktu widzenia [...]. Chrematonimy wchodzą w skład wielu typów dyskursów: na plan pierwszy wysuwa się przestrzeń informacji, identyfikowania otaczających nas przedmiotów, uczestniczenia w takich specjalnych odmianach komunikacji społecznej, jak język marketingu, język reklamy, terminologie specjalistyczne, język urzędowy, język religijny, język artystyczny, język techniczny, ,netjęzyk” itd. [Gałkowski, 2008, s. 56; o odkrywczości, walorach i nowatorstwie książki Gałkowskiego zob. Walczak, 2010].

W tym krótkim szkicu pragnąłbym zwrócić uwagę na jedną właściwość współczesnej szeroko rozumianej chrematonimii. Uważna lektura książki A. Gałkowskiego pozwala przypuszczać, że jej autor sobie tę właściwość uświadamiał, jednak expressis verbis tej swojej świadomości nie wyartykułował. Chodzi o to, że spośród wszystkich rodzajów nazw własnych (jak geonimy, antroponimy, teonimy, kosmonimy itd., ze wszystkimi ich bardziej szczegółowymi odmianami) chrematonimy w relatywnie największym stopniu wykazują paralelizm rozwojowy w odniesieniu do leksyki apelatywnej (co notabene mogłoby dodatkowo świadczyć o ich przejściowym, pośrednim charakterze, na co jednak - w tym kontekście - o ile mi wiadomo, nikt dotąd nie zwrócił uwagi).

Zasób leksykalny współczesnego języka polskiego ulega nasilającemu się oddziaływaniu innych języków [Walczak, 1994, 2003], wśród których na pierwsze miejsce wysuwa się angielski jako dzisiejszy język międzynarodowy [Mańczak-Wohlfeld, 1994]. Wpływy angielskie wykraczają już dziś nawet poza obszar słownictwa i frazeologii, sięgając do jądra systemu gramatycznego polszczyzny [Walczak, 1995]. W dyskursie społeczno-kulturowym pojawiają się nawet 
(choć formułowane raczej przez niespecjalistów) opinie o tym, że w nieodległej przyszłości fala angielszczyzny może nas zalać, kładąc kres naszej tożsamości językowej i kulturowej [Walczak, 2008]. Nie wygasają też (choć znacznie słabsze niż w przeszłości) wpływy języka francuskiego, który jest w tym względzie aktywny zwłaszcza jako źródło nowych zapożyczeń z zakresu mody, szczególnie damskiej, i kuchni [Walczak, 1992, 1994], a galicyzmom kulinarnym towarzyszą narastające liczebnie w tym polu semantycznym zapożyczenia włoskie [Walczak, 1994, 2003]. Wespół z innymi zjawiskami, nasilające się oddziaływanie wielkich języków o randze ponadlokalnej skłania do rozpatrywania i interpretowania współczesnych zmian w polszczyźnie w kontekście procesu globalizacji, rozumianej jako proces unifikacji instytucji, narodów, państw itd., poddanych działaniu zjawisk gospodarczych o światowym zasięgu i korzystających z najnowszych zdobyczy cywilizacji naukowo-technicznej [Walczak, 2011, 2013].

Wszystkie te zjawiska i procesy ujawniają się przynajmniej równie silnie i wyraziście (jeśli nie silniej i wyraziściej) jak w obszarze leksyki apelatywnej - na gruncie chrematonimii. A. Gałkowski, jako autor najważniejszej polskiej monografii chrematonomastycznej, potwierdza zasadność powszechnego przekonania o supremacji angielszczyzny w obszarze chrematonimii marketingowej:

Wnioski, powtarzające się w wielu analizach chrematonimów marketingowych pod kątem udziału w ich budulcu elementów obcojęzycznych, zgodnie potwierdzają, że największą popularnością cieszy się w tym dziale nazewniczym język angielski. Jest to język, który utwierdza swoją pozycję języka międzynarodowego w różnych dziedzinach życia wszystkich krajów europejskich. Wzmacnia ten trend postępujący proces amerykanizacji kultur, czyli kształtowania elementów kultury globalnej na wzór modeli zza oceanu [Gałkowski, 2008, s. 318].

Łódzki onomasta wykazał też - co już nie należy do opinii powszechnych paralelny do sytuacji w słownictwie apelatywnym duży udział elementów francuskich i włoskich w polskim nazewnictwie marketingowym:

Zaskakująca ilość odnalezionych nazw, będących bezpośrednim lub pośrednim nawiązaniem do języka włoskiego oraz francuskiego [...] przekonuje, że języki te oraz kraje, które one reprezentują, nie przestają wywoływać pozytywnych skojarzeń wśród Polaków. Podobają się z powodu ich formalnej struktury i kultur, do których należą. Charakter foniczny i graficzny obu języków jest powszechnie rozpoznawany [...]. W świadomości społecznej wytworzyły się pewne obrazy oraz stereotypy pozwalające uważać aspekty języka włoskiego i francuskiego za cenne elementy kultury ludzkiej w ogóle. Mówi się np. o finezji, elegancji, wdzięku, uprzejmości, dobrej kuchni, modzie, subtelności à la française oraz radości, żywiołowości, szczerości, otwartości, muzykalności, estetyce, cieple, urodzie, egzotyce à l'italienne [Gałkowski, 2008, s. 320]. 
Dostarczył również A. Gałkowski niepodważalnych świadectw procesów globalizacyjnych na gruncie chrematonimii. Niezależnie od przytoczonej wyżej opinii o postępującej amerykanizacji kultur, łódzki onomasta trafnie zinterpretował fundamentalny $\mathrm{w}$ tym kontekście proces internacjonalizacji (a więc i globalizacji) firmonimów:

W dzisiejszych czasach nazwy marek, szczególnie tych najpopularniejszych, stały się podstawowym elementem nowej lingua franca. To, co spotykamy, zapamiętujemy i nazywamy zgodnie z nadanym identyfikatorem słownym w jednym kraju, odnajdziemy również w innym. Przy czym nie można wykluczyć, że dziś nieznane jeszcze, jako internacjonalizmy, marki typowo narodowe nie staną się lada moment elementem innego języka. Decyduje o tym sukces ekonomiczny firmy, zapotrzebowanie na jej produkt, zabiegi marketingowe (kampanie promocyjne, medialne, reklama, współpraca gospodarcza). Można śmiało stwierdzić, że w zakresie nazewnictwa marketingowego we współczesnym świecie zacierają się różnice językowe i tworzy się chrematonomastykon firm, wspólny wielu krajom i językom [Gałkowski, 2008, s. 96].

Żadna inna kategoria onimiczna nie wykazuje takich paralel rozwojowych w odniesieniu do ewolucji apelatywnego pionu języka. Nazwy miejscowe i terenowe, hydronimy, oronimy itd., a także - z zakresu antroponimii - nazwiska w zasadzie w ogóle nie podlegają współczesnym wpływom obcym i tendencji do internacjonalizacji czy globalizacji [zob. Walczak, 2004]. Imiona chrzestne, jako kategoria w zasadzie leksykalnie zamknięta, ulegają tym tendencjom i procesom w stopniu minimalnym (jest tak mimo niewątpliwego nacisku społecznego: nowe modne imiona w obcym kształcie językowym z trudem zyskują sobie prawo obywatelstwa na skutek oddziałującego w tym względzie hamująco czynnika normatywno-kodyfikacyjnego). Jedynie przezwiska zachowują się w znacznym stopniu porównywalnie do chrematonimów. Jak wynika z badań Kazimierza Długosza, rośnie odsetek przezwisk, które są wynikiem oddziaływania innych języków na polszczyznę. Szczeciński antroponomasta serię artykułów, obrazujących oddziaływanie na przezwiska młodzieżowe różnych języków europejskich, zwieńczył pracami syntetycznymi [Długosz, 1998 i 2003; o tej drugiej, obszernej monografii książkowej, Ewa Kołodziejek napisała: „Książka ta jest owocem wieloletnich zainteresowań autora przezwiskami młodzieżowymi, pokazuje także intensywność oddziaływania języków obcych na współczesną polszczyznę mówioną" - 2006, s. 8]. Nie ulega wątpliwości, że paralele między chrematonimami a przezwiskami wynikają z tego, że także przezwiska (ze względu na zachowaną w dużej mierze motywację, to znaczy na zachowaną zdolność charakteryzowania - w sposób bezpośredni lub pośredni - nosicieli) stanowią kategorię onimiczną przejściową, 
pośrednią między nazwami własnymi a wyrazami pospolitymi [Skulina, 1974; Kosyl, 2001].

Onomaści poświęcają dziś chrematonimii coraz więcej uwagi. Ze względu na jej szczególny status onimiczny i nie do końca przewidywalne właściwości wydaje się to ze wszech miar uzasadnione.

\section{BIBLIOGRAFIA}

DŁugosz Kazimierz, 1998, Elementy obce w strukturze współczesnego przezwiska polskiego, w: Przezwiska i przydomki w językach słowiańskich, cz. 1, red. J. Warchoł, Lublin, s. 102-119.

DŁugosz Kazimierz, 2003, Współczesne „europejskie” nazwy młodzieżowe, Szczecin.

GAŁKOwSKi Artur, 2008, Chrematonimy w funkcji kulturowo-użytkowej. Onomastyczne studium porównawcze na materiale polskim, włoskim, francuskim, Łódź.

KoŁodziejek Ewa, 2006 Profesor Kazimierz Długosz, w: W kręgu polszczyzny dawnej i współczesnej, Szczecin, s. 7-10.

Kosyl Czesław, 2001, Nazwy osobowe, w: Współczesny język polski, red. J. Bartmiński, Lublin, s. 431-445.

Kosyl Czesław, 2001, Chrematonimy, w: Współczesny język polski, red. J. Bartmiński, Lublin, s. 447-452.

LEWANDOWSKI Andrzej, 1992, Współczesne polskie nazwy firmowe, Zielona Góra.

MaŃCZAK-Wohlfeld Elżbieta, 1994, Angielskie elementy leksykalne w języku polskim, Kraków.

SkULINA Tadeusz, 1974, Funkcje przezwiska w systemie antroponimicznym, „Studia z Filologii Polskiej i Słowiańskiej”, 13, s. 213-234.

WaLcZAK Bogdan, 1992, Najnowsze (powojenne) zapożyczenia francuskie w języku polskim, w: Z badań nad współczesną polszczyzną, red. E. Homa, Szczecin, s. 97-109.

WALCZAK Bogdan, 1994, Powojenne galicyzmy w języku polskim, „Sprawozdania Poznańskiego Towarzystwa Przyjaciół Nauk, Wydział Filologiczno-Filozoficzny", 107, 2, s. 165-169.

Walczak Bogdan, 1994, Wpływy obce w powojennej polszczyźnie, w: Przemiany współczesnej polszczyzny, red. S. Gajda, Z. Adamiszyn, Opole, s. 223-228.

WALCZAK Bogdan, 1995, Norma językowa wobec elementów obcego pochodzenia, w: Kultura języka dziś, red. W. Pisarek, H. Zgółkowa, Poznań, s. 120-133. 
WalczaK Bogdan, 2000, Nazwy firmowe: propria czy appellativa?, w: Onomastyka polska a nowe kierunki językoznawcze, red. M. Czachorowska, Ł.M. Szewczyk, Bydgoszcz, s. 113-122.

WalCZAK Bogdan, 2003, Nowe zapożyczenia w polszczyźnie drugiej połowy $\mathrm{XX}$ wieku, w: Ulotność i trwanie. Studia z tematologii i historii literatury, red. E. Wiegandt, A. Czyżak, Z. Kopeć, Poznań, s. 265-275.

WalczaK Bogdan, 2004, Dzieje języka a nazwy własne, w: Nazwy własne w języku, kulturze i komunikacji społecznej, red. R. Mrózek, Katowice, s. 29-44.

WalczaK Bogdan, 2008, Czy językowi polskiemu coś zagraża?, w: Współczesna polszczyzna. Stan - Perspektywy - Zagrożenia, red. Z. Cygal-Krupa, Kraków - Tarnów, s. 15-24.

WalczaK Bogdan, 2010, [Rec.] Artur Gałkowski, Chrematonimy w funkcji kulturowo-użytkowej. Onomastyczne studium porównawcze na materiale polskim, włoskim, francuskim, „Poradnik Językowy”, 3, s. 111-113.

WALCZAK Bogdan, 2011, Język wobec procesów globalizacji, „Annales Universitatis Paedagogicae Cracoviensis”, 107, „Studia Linguistica” VI (Dialog z tradycją, cz. 1, red. S. Koziara, E. Młynarczyk, B. Skowronek), s. 12-20.

WALCZAK Bogdan, 2013, Komunikacja językowa w perspektywie globalizacji i sytuacji językowej współczesnego świata, w: Dyskursy trzeciego tysiąclecia II, red. E. Pajewska, Szczecin, s. 203-216. 